\title{
Serum chitinase-like protein YKL-40 is linked to small airway function in children with asthmatic symptoms
}

\section{Knihtilä, Hanna}

2019-12

Knihtilä , H , Kotaniemi-Syrjänen , A , Pelkonen , A S , Savinko , T , Malmberg , L P \& Mäkelä, M J 2019 , ' Serum chitinase-like protein YKL-40 is linked to small airway function in children with asthmatic symptoms ' , Pediatric Allergy and Immunology , vol. 30 , no. 8 , pp. 803-809 . https://doi.org/10.1111/pai.13119

http://hdl.handle.net/10138/314802

https://doi.org/10.1111/pai.13119

acceptedVersion

Downloaded from Helda, University of Helsinki institutional repository.

This is an electronic reprint of the original article.

This reprint may differ from the original in pagination and typographic detail.

Please cite the original version. 


\title{
Serum chitinase-like protein YKL-40 is linked to small airway function in children with asthmatic symptoms
}

\author{
Hanna Knihtilä, MD, PhD; Anne Kotaniemi-Syrjänen, MD, PhD; Anna S. Pelkonen, \\ MD, PhD; Terhi Savinko, PhD; ${ }^{a}$ L. Pekka Malmberg, MD, PhD; a Mika J. Mäkelä, MD, \\ $\mathrm{PhD}{ }^{\mathrm{a}}$ \\ aDepartment of Allergology, University of Helsinki and Helsinki University Hospital, \\ Helsinki, Finland
}

Running title: YKL-40 and lung function in asthmatic children

Correspondence: Hanna Knihtilä, HUH Skin and Allergy Hospital, P.O. Box 160, 00029 HUS, Finland, e-mail: hanna.knihtila@helsinki.fi

i. Conflicts of Interest: The authors have no conflicts of interest to declare.

ii. Financial support: The study was funded by the Finnish Society of Allergology and Immunology, Emil Aaltonen Foundation, Foundation for Pediatric Research, Ida Montin's Foundation, The Finnish Allergy Research Foundation, The Finnish Medical Foundation, The Research Foundation of the Pulmonary Diseases, The Sigrid Juselius Foundation, and Väinö and Laina Kivi’s Foundation.

\section{iii. Abstract and keywords}

Background: Lung function impairment among asthmatics begins in early life and biomarkers for identifying this impairment are needed. The chitinase-like protein YKL-40 has been associated with asthma and lung function in adults but studies in children have yielded conflicting results. We

This article has been accepted for publication and undergone full peer review but has not been through the copyediting, typesetting, pagination and proofreading process, which may lead to differences between this version and the Version of Record. Please cite this article as doi: 10.1111/pai.13119

This article is protected by copyright. All rights reserved. 
evaluated the potential of YKL-40 and other systemic biomarkers for identifying asthmatic lung function deficits in children.

Methods: We determined the levels of serum YKL-40, periostin, and high-sensitivity C-reactive protein (hs-CRP) from the blood samples of 49 children with asthmatic symptoms. Lung function was assessed with impulse oscillometry (IOS) and spirometry, combined with an exercise challenge and a bronchodilator test. Fractional exhaled nitric oxide was measured at multiple flow rates.

Results: Serum levels of YKL-40 showed significant correlations with most IOS indices at baseline $(\mathrm{p}=0.008-0.039)$, but there was no association between YKL-40 and spirometry parameters. Neither periostin nor hs-CRP were associated with baseline lung function. Children with a significant response in either the exercise challenge or the bronchodilator test had increased serum levels of YKL-40 ( $\mathrm{p}=0.003)$ and periostin $(\mathrm{p}=0.035)$. YKL-40 correlated significantly with the blood neutrophil count $\left(\mathrm{r}_{\mathrm{s}}=0.397, \mathrm{p}=0.005\right)$ but was not associated with biomarkers of eosinophilic inflammation.

Conclusion: Serum YKL-40 is a potential biomarker for lung function deficits in children with asthmatic symptoms. These deficits appear to be focused on small airways and may remain undetected with spirometry.

Keywords: YKL-40, asthma, respiratory function tests, airway resistance, spirometry

\section{iv. Main text}

\section{INTRODUCTION}

Asthmatic subjects often present with decreased lung function, and a substantial proportion of the lung function deficits are detectable in early childhood (1). In a subgroup, deterioration of lung function progresses through adolescence and may lead to irreversible airflow obstruction (2).

This article is protected by copyright. All rights reserved. 
Biomarkers for early identification of subjects with abnormal lung function are crucial for optimizing the treatment and follow-up of these patients.

YKL-40 is a chitinase-like protein found in humans that binds chitin but lacks enzymatic activity (3). The biological significance of YKL-40 is incompletely understood, but increased levels of serum YKL-40 have been observed in diseases involving infection, inflammation, and tissue remodeling (4). In adults, increased serum YKL-40 has been associated with asthma, and its levels correlate with increasing disease severity and bronchial wall thickness as well as decreasing lung function (3-5). However, the significance of YKL-40 in childhood asthma remains unclear, and no association between YKL-40 and lung function assessed with spirometry or airway hyperreactivity has been observed in children $(3,6,7)$. Other potentially useful biomarkers in asthma include periostin which is related to $\mathrm{T}$ helper type $2\left(\mathrm{~T}_{\mathrm{H}} 2\right)$ induced airway inflammation and high-sensitivity C-reactive protein (hs-CRP) which increases in different conditions related to low-grade systemic inflammation (8).

Asthmatic inflammation involves both small and large airways (9). However, spirometry mainly reflects the function of larger airways. Impulse oscillometry (IOS) uses pulse signals of different frequencies to determine respiratory resistance and reactance. Based on computational models, highfrequency resistance values, such as respiratory resistance at $20 \mathrm{~Hz}$ (R20) are considered to reflect large airway function, whereas low-frequency resistance, such as respiratory resistance at $5 \mathrm{~Hz}$ (R5) reflect the whole respiratory tract (10). Potential manifestations of small airway obstruction and alveolar tissue involvement include increased difference between R5 and R20 (R5-20, i.e. frequencydependence of resistance) and decreased low-frequency reactance values, such as respiratory reactance at $5 \mathrm{~Hz}(\mathrm{X} 5)$, which result in increased area under the reactance curve (AX) (10).

We aimed to clarify the role of YKL-40, periostin, and hs-CRP in childhood asthma. Therefore, we investigated their association with lung function in children with asthmatic symptoms using IOS and spirometry indices which have the potential of reflecting different parts of the respiratory tract. In addition, we evaluated their relationship with airway hyperreactivity (AHR) and bronchodilator

This article is protected by copyright. All rights reserved. 
responsiveness (BDR). We also examined their associations with other blood and exhaled inflammatory biomarkers.

\section{METHODS}

\section{Subjects}

In total, 58 children (aged 5-10 years) were recruited among patients referred to the Skin and Allergy Hospital, Helsinki University Hospital, Finland, because of symptoms indicating probable asthma, such as recurrent wheezing, persistent troublesome cough, and shortness of breath during exercise (11). Baseline IOS and spirometry measurements followed by an exercise challenge and a bronchodilator test were performed at the first visit. Extended fractional exhaled nitric oxide (FeNO) measurements were performed at the second visit within 14 days. All children were free from respiratory tract infections for $\geq 2$ weeks, and possible asthma-control medications were ceased $\geq 4$ weeks prior to the lung function measurements.

\section{Allergic sensitization and serologic analyses}

Allergic sensitization was defined as a serum-specific IgE level of $\geq 0.35 \mathrm{kU} / 1$ or a skin prick test wheal diameter of $\geq 3 \mathrm{~mm}$ to $\geq 1$ aeroallergens: birch, timothy grass, meadow fescue, mugwort, Cladosporium herbarum, cat, dog, horse, and Dermatophagoides pteronyssinus.

Venous blood samples were collected and blood eosinophil and neutrophil counts were determined at the time of recruitment. Additional serum samples were stored in $-40^{\circ} \mathrm{C}$ and used to determine $\mathrm{YKL}-$ 40 and periostin proteins with Human Chitinase 3-like 1 DuoSet ELISA kit (Biotechne, UK) and Human Periostin/OSF-2 DuoSet ELISA kit (Biotechne, UK). All reagents were purchased from Biotechne (DuoSet Ancillary Reagent Kit 2). Briefly, serum samples were diluted 1:10, 1:20, and 1:40 with reagent diluent and sandwich ELISA performed according to manufactures instructions. Serum hs-CRP was determined using an immunoturbidimetric assay (CRPHS; RocheDiagnostics GmbH, Mannheim, Germany).

This article is protected by copyright. All rights reserved. 


\section{Lung function and inflammation}

Baseline IOS (Masterscreen IOS, Carefusion, Hoechberg, Germany), spirometry (Masterscreen Pneumo, Carefusion, Hoechberg, Germany), and FeNO at $50 \mathrm{ml} / \mathrm{s}\left(\mathrm{FeNO}_{50}, \mathrm{CLD} 88\right.$, Ecomedics, Duernten, Switzerland) measurements were performed according to international recommendations (12-14), as described earlier (11). For IOS, $\geq 3$ regular breathing patterns lasting $\geq 20$ seconds were recorded, and the mean of each parameter was used in the analyses. Figure 1 illustrates the main IOS parameters. In spirometry, the highest values of forced expiratory volume in one second $\left(\mathrm{FEV}_{1}\right)$ and forced vital capacity (FVC) were selected from the $\geq 3$ successful measurements recorded, and flow indices were derived from the curve with the largest sum of $\mathrm{FEV}_{1}$ and FVC. FeNO was measured at $30,50,100$, and $200 \mathrm{ml} / \mathrm{s}$ and alveolar nitric oxide concentration $\left(\mathrm{C}_{\mathrm{ALV}}\right)$ was calculated from the twocompartment linear model (15) using two technically successful measurements for three different flow rates: 100, 200, and either 30 or $50 \mathrm{ml} / \mathrm{s}$ for achieving the best goodness of fit.

\section{Airway hyperreactivity and bronchodilator responsiveness}

An outdoor free running test was performed as described earlier (16) using either IOS or spirometry based on the age and cooperation of the child. Lung function was measured at 1, 5, and 10 minutes after exercise, and the test was considered positive for significant AHR if R5 increased $\geq 35 \%$ (16) from the baseline value or $\mathrm{FEV}_{1}$ decreased $\geq 15 \%$ (17) at any of these time points.

After the exercise challenge, 300 micrograms of salbutamol (Ventoline, Glaxo, UK) was given to the children via Babyhaler® spacer (Glaxo, UK) and both IOS and spirometry measurements were repeated 10-15 minutes after the inhalation. Significant BDR was defined as a decrease of $\geq 40 \%$ (18) from the baseline value in $\mathrm{R} 5$ or an increase of $\geq 12 \%$ (19) in $\mathrm{FEV}_{1}$.

\section{Statistical analyses}

Normality of the variables was evaluated with Shapiro-Wilk test. Spearman's correlation test was used to evaluate association between continuous variables and Mann-Whitney $\mathrm{U}$ test for comparisons between groups. Z-score values of IOS, spirometry, and $\mathrm{FeNO}_{50}$ were determined based on national

This article is protected by copyright. All rights reserved. 
reference equations $(18,20-22)$. Two-tailed tests with a significance level of 0.05 were used. The data were analyzed with IBM SPSS Statistics version 25 and $\mathrm{R}$ version 3.3.3.

\section{Ethics}

The study was approved by Helsinki University Hospital (ID number: IAS16 ASA04 0116) and Helsinki University Hospital Research Ethics Committee (approval number: 390/13/03/03/2015), and it was conducted in compliance with the Declaration of Helsinki. Parents of all participating children provided a written consent, and depending on literacy, the children contributed an oral or a written consent.

\section{RESULTS}

\section{Characteristics of the study subjects}

Figure 2 illustrates a flowchart of the study. From the 50 children with serum samples collected, one child was excluded from all analyses because of rheumatoid arthritis and its possible influence on the investigated serum biomarkers (4). Two children had obstruction at baseline and therefore, exercise challenge was not performed, but the children were included in other analyses. Table 1 presents the baseline characteristics and lung function of the study children. YKL-40, periostin, and hs-CRP were unrelated to age, height, gender ( $p>0.05$ for all analyses, data not shown), and allergic sensitization, but hs-CRP was associated with weight and body mass index $\left(r_{s}=0.304, p=0.034\right.$ and $r_{s}=0.331$, $\mathrm{p}=0.020$, respectively). 11 children $(22 \%)$ used continuous inhaled corticosteroid (one in combination with montelukast and one with salmeterol) and one child (2\%) used continuous montelukast which were ceased $\geq 4$ weeks before the lung function measurements. None of the children used specific immunotherapy. YKL-40, periostin, and hs-CRP did not significantly differ between children with or without asthma control medication use before study participation (median $31.7 \mathrm{vs.} 22.3 \mathrm{ng} / \mathrm{ml}$, $\mathrm{p}=0.170$ for $\mathrm{YKL}-40$; median 53.9 vs. $52.9 \mathrm{ng} / \mathrm{ml}, \mathrm{p}=0.871$ for periostin; and median 0.46 vs. 0.32 $\mathrm{mg} / \mathrm{l}, \mathrm{p}=0.972$ for hs-CRP, respectively).

This article is protected by copyright. All rights reserved. 


\section{Serum biomarkers and lung function}

YKL-40 significantly correlated with the absolute and z-score values of all baseline IOS indices except for R20 (Table 2) but was unrelated to the absolute and z-score values of the spirometry indices ( $p>0.05$ for all analyses, data not shown). Periostin and hs-CRP were not associated with any of the IOS or spirometry indices ( $p>0.05$ for all analyses).

In total, 18 children (39\%) showed significant AHR and 10 children (20\%) showed significant BDR. IOS was used as an endpoint measure of the exercise challenge in 25 children with 10 (40\%) showing significant AHR and spirometry in 21 children with 8 (38\%) demonstrating significant AHR. Children with a positive AHR or BDR test result had significantly higher levels of serum YKL-40 and periostin than those with normal results (Figure 3). Hs-CRP did not differ between children with or without significant AHR or BDR ( $\mathrm{p}=0.311)$.

\section{Associations between different markers of inflammation}

YKL-40 correlated significantly with blood neutrophil count $\left(\mathrm{r}_{\mathrm{s}}=0.397, \mathrm{p}=0.005\right)$ but was not associated with hs-CRP $\left(\mathrm{r}_{\mathrm{s}}=0.211, \mathrm{p}=0.146\right)$ or any of the blood or exhaled biomarkers related to eosinophilic inflammation: $\mathrm{r}_{\mathrm{s}}=0.159$ and $\mathrm{p}=0.276$ for blood eosinophil count; $\mathrm{r}_{\mathrm{s}}=0.174$ and $\mathrm{p}=0.232$ for periostin; $\mathrm{r}_{\mathrm{s}}=0.088$ and $\mathrm{p}=0.549$ for $\mathrm{FeNO}_{50}$; and $\mathrm{r}_{\mathrm{s}}=0.117$ and $\mathrm{p}=0.422$ for $\mathrm{C}_{\mathrm{ALV}}$.

Periostin correlated significantly with blood eosinophil count $\left(\mathrm{r}_{\mathrm{s}}=0.412, \mathrm{p}=0.003\right)$ but not with blood neutrophil count $\left(\mathrm{r}_{\mathrm{s}}=-0.125, \mathrm{p}=0.393\right), \mathrm{FeNO}_{50}\left(\mathrm{r}_{\mathrm{s}}=0.099, \mathrm{p}=0.500\right)$, or $\mathrm{C}_{\mathrm{ALV}}\left(\mathrm{r}_{\mathrm{s}}=0.018, \mathrm{p}=0.912\right)$. HsCRP correlated with blood neutrophil count $\left(\mathrm{r}_{\mathrm{s}}=0.440, \mathrm{p}=0.002\right)$ but showed no association with blood eosinophil count $\left(\mathrm{r}_{\mathrm{s}}=-0.119, \mathrm{p}=0.415\right), \mathrm{FeNO}_{50}\left(\mathrm{r}_{\mathrm{s}}=-0.049, \mathrm{p}=0.737\right)$, or $\mathrm{C}_{\mathrm{ALV}}\left(\mathrm{r}_{\mathrm{s}}=-0.086, \mathrm{p}=0.601\right)$.

\section{DISCUSSION}

We demonstrate a significant association between serum YKL-40 and lung function in children with asthmatic symptoms. This association was consistent throughout all IOS indices related to small

This article is protected by copyright. All rights reserved. 
airway function but was not observed with R20 or with spirometry indices, both of which are considered to reflect mainly larger airway function. YKL-40 was also increased in children with significant AHR or BDR, supporting its role as a possible biomarker of lung function deficits in childhood asthma.

In adults, YKL-40 has been associated with lung function and AHR (3). In children, no association between YKL-40 and spirometry has been observed $(6,7)$, but an association between YKL-40 and airway wall thickness has been observed in adults and children $(5,6)$. We found significant correlations between YKL-40 and all IOS indices related to small airway function: R5, R5-20, X5, and AX (10), which remained significant with both absolute and the height- and sex-adjusted z-score IOS values. However, YKL-40 was unrelated to R20 and spirometry indices. Therefore, early lung function deficits related to increased YKL-40 may be focused on small airways and remain undetectable with spirometry, which is relatively insensitive to early small airway pathology (9). It is also possible that inhaled corticosteroids, which were ceased $\geq 4$ weeks before the lung function measurements in our study, could interfere with the association between YKL-40 and lung function and explain the lack of correlation in previous studies. Nevertheless, we previously observed that frequency-dependence of respiratory resistance in preschool IOS correlated with lung function in adolescence among asthmatic subjects (23), supporting the notion that early lung function deficits in asthma can be focused on small airways. These findings highlight the need for tools to assess small airway function. However, further research is required to determine the persistence and longitudinal progression of lung function deficits that manifest as increased YKL-40.

The molecular mechanisms underlying the effects of YKL-40 in asthma are unclear. In vitro and in vivo animal studies have found a connection between that $\mathrm{YKL}-40$ and $\mathrm{T}_{\mathrm{H}} 2$-mediated inflammation (4). However, clinical studies have found associations between $\mathrm{YKL}-40$ and $\mathrm{T}_{\mathrm{H}} 2$-related biomarkers weak or nonexistent $(6-8,24)$. We found no association between YKL-40 and blood or exhaled biomarkers of eosinophilic inflammation. Interestingly, we did observe a significant correlation between YKL-40 and blood neutrophils, which is consistent with a previous study in asthmatic children (6). Accordingly, Gomez et al. (24) showed that adult asthma phenotypes with high serum

This article is protected by copyright. All rights reserved. 
YKL-40 had increased sputum neutrophils, whereas increased $\mathrm{T}_{\mathrm{H}} 2$ markers were related to low YKL40.

YKL-40 has been proposed as a marker of airway remodeling (4), and it can promote bronchial smooth muscle cell proliferation and migration as well as collagen production by lung fibroblasts $(25,26)$. Accordingly, Chupp et al. (5) observed that subepithelial basement membrane thickness correlated with increasing expression of YKL-40 in the bronchial biopsies of asthmatic subjects. Bronchial biopsies of preschool children with asthmatic symptoms have demonstrated pathological changes related to airway remodeling, indicating that chronic inflammation might not be a prerequisite for detectable histological changes but rather a parallel process in the disease pathophysiology (4). Therefore, noninvasive markers of the progression of airway remodeling are necessitated. We found that YKL-40 correlated with lung function in children with early signs of asthma and the association was independent of markers of eosinophilic inflammation, highlighting the potential complementary role of YKL-40 as a biomarker for early asthmatic lung function impairment. Indirect markers of airway remodeling have been associated with decreased BDR in asthmatic adults (27), but the clinical effects of early airway remodeling in asthmatic children remain unclear (28), and further studies are needed to evaluate the association between YKL-40 and possible decreases in BDR in children with confirmed asthma.

Neither periostin, nor hs-CRP were associated with baseline lung function. However, similar to YKL40, periostin was increased in children with significant AHR or BDR. This is consistent with previous findings on the association between periostin and AHR in children (29). Periostin has been related to $\mathrm{T}_{\mathrm{H}}$ 2-type inflammation and increased serum periostin levels are seen in blood and airway eosinophilia (8). Accordingly, we observed a positive correlation between periostin and blood eosinophils.

However, periostin was unrelated to $\mathrm{FeNO}_{50}$ and $\mathrm{C}_{\mathrm{ALV}}$ which might be related to the relatively small study sample or possibly to the time between FeNO measurements and blood sample collection, as weak associations between periostin and FeNO have been previously reported (8). We found no associations between hs-CRP and lung function or FeNO and therefore, further studies are needed to elucidate its potential usefulness in pediatric asthma.

This article is protected by copyright. All rights reserved. 
This study has some limitations. Our sample size was limited and the patient population consisted of children with mild to moderate symptoms, leaving out patients with severe pediatric asthma. Another limitation is that all available techniques reflect indirect changes related to small airway function and the presence of small airway dysfunction cannot be conclusively determined. Besides parallel ventilation heterogeneity related to small airway obstruction, frequency-dependence of respiratory resistance can be affected by upper airway shunt properties and respiratory tissue viscoelasticity (30). Furthermore, the association between YKL-40 as well as periostin and AHR was significant only when excluding children with a significant BDR from the negative group which complicates the physiological interpretation of this finding. Nevertheless, both AHR and BDR are hallmarks of asthma and a significant result in either of these tests is often used to classify patients with susceptible symptoms as having asthma. However, it should be acknowledged that none of the available tests can diagnose asthma or different subtypes of the disease in young children decisively which results in heterogeneity within patient populations.

In conclusion, we established a significant association between serum chitinase-like protein YKL-40 and lung function in children with asthmatic symptoms. This association was focused on indices that reflect small airway function, which might explain the lack of association with spirometry. YKL-40 was also increased in children with significant AHR or BDR. Therefore, YKL-40 appears as a potential biomarker of lung function impairment in asthmatic children. Further studies are needed to clarify the mechanisms and longitudinal progression of the observed associations.

\section{v. Acknowledgements}

We express our gratitude to Research Nurse Anssi Koivuselkä for performing the lung function measurements.

This article is protected by copyright. All rights reserved. 


\section{vi. References}

1. Sears MR, Greene JM, Willan AR et al. A Longitudinal, Population-Based, Cohort Study of Childhood Asthma Followed to Adulthood. N Engl J Med 2003: 349:1414-1422.

2. McGeachie MJ, Yates KP, Zhou X et al. Patterns of Growth and Decline in Lung Function in Persistent Childhood Asthma. N Engl J Med 2016: 374:1842-1852.

3. Ober C, Tan Z, Sun Y et al. Effect of variation in CHI3L1 on serum YKL-40 level, risk of asthma, and lung function. N Engl J Med 2008: 358:1682-1691.

4. Lee CG, Da Silva CA, Cruz Dela CS et al. Role of Chitin and Chitinase/Chitinase-Like Proteins in Inflammation, Tissue Remodeling, and Injury. Annu Rev Physiol 2011; 73:479501.

5. Chupp GL, Lee CG, Jarjour $\mathrm{N}$ et al. A chitinase-like protein in the lung and circulation of patients with severe asthma. N Engl J Med 2007: 357:2016-2027.

6. Konradsen JR, James A, Nordlund B et al. The chitinase-like protein YKL-40: a possible biomarker of inflammation and airway remodeling in severe pediatric asthma. J Allergy Clin Immunol 2013: 132:328-35.

7. Santos CB, Davidson J, Covar RA et al. The chitinase-like protein YKL-40 is not a useful biomarker for severe persistent asthma in children. Ann Allergy Asthma Immunol 2014: 113:263-266.

8. Jia G, Erickson RW, Choy DF et al. Periostin is a systemic biomarker of eosinophilic airway inflammation in asthmatic patients. J Allergy Clin Immunol 2012: 130:647-654.e10.

9. van den Berge M, Hacken ten NHT, van der Wiel E et al. Treatment of the bronchial tree from beginning to end: targeting small airway inflammation in asthma. Allergy 2013: 68:16-26.

This article is protected by copyright. All rights reserved. 
10. Allen JL. Input oscillometry and the forced oscillation technique for assessing lung function in preschool children with asthma. Pediatric Investigation 2018: 2:37-43.

11. Knihtilä H, Kotaniemi-Syrjänen A, Pelkonen AS et al. Small airway function in children with mild-to-moderate asthmatic symptoms and healthy controls. Ann Allergy Asthma Immunol 2018; 121:451-457.

12. Beydon N, Davis SD, Lombardi E et al. An official American Thoracic Society/European Respiratory Society statement: pulmonary function testing in preschool children. Am J Respir Crit Care Med 2007: 175:1304-1345.

13. Miller MR, Hankinson J, Brusasco V et al. Standardisation of spirometry. Eur Respir J 2005: 26:319-338.

14. Baraldi E, de Jongste JC, European Respiratory Society/American Thoracic Society (ERS/ATS) Task Force. Measurement of exhaled nitric oxide in children, 2001. Eur Respir J 2002: 20:223-237.

15. Tsoukias NM, George SC. A two-compartment model of pulmonary nitric oxide exchange dynamics. J Appl Physiol 1998: 85:653-666.

16. Malmberg LP, Mäkelä MJ, Mattila PS et al. Exercise-induced changes in respiratory impedance in young wheezy children and nonatopic controls. Pediatr Pulmonol 2008: 43:538544.

17. Parsons JP, Hallstrand TS, Mastronarde JG et al. An official American Thoracic Society clinical practice guideline: exercise-induced bronchoconstriction. Am J Respir Crit Care Med 2013: 187:1016-1027.

18. Malmberg LP, Pelkonen A, Poussa T et al. Determinants of respiratory system input impedance and bronchodilator response in healthy Finnish preschool children. Clin Physiol Funct Imaging 2002: 22:64-71.

This article is protected by copyright. All rights reserved. 
19. Pellegrino R, Viegi G, Brusasco V et al. Interpretative strategies for lung function tests. Eur Respir J 2005: 26:948-968.

20. Knihtilä H, Kotaniemi-Syrjänen A, Pelkonen AS et al. Sensitivity of newly defined impulse oscillometry indices in preschool children. Pediatr Pulmonol 2016: 52:598-605.

21. Koillinen H, Wanne $\mathrm{O}$, Niemi $\mathrm{V}$ et al. Reference values for flow-volume spirometry and peak expiratory flow rates in healthy Finnish children. Finn Med J 1998:395-402.

22. Malmberg LP, Petäys T, Haahtela T et al. Exhaled nitric oxide in healthy nonatopic school-age children: determinants and height-adjusted reference values. Pediatr Pulmonol 2006: 41:635642.

23. Knihtilä H, Kotaniemi-Syrjänen A, Mäkelä MJ et al. Preschool oscillometry and lung function at adolescence in asthmatic children. Pediatr Pulmonol 2015: 50:1205-1213.

24. Gomez JL, Yan X, Holm CT et al. Characterisation of asthma subgroups associated with circulating YKL-40 levels. Eur Respir J 2017: 50:1700800.

25. Bara I, Ozier A, Girodet P-O et al. Role of YKL-40 in bronchial smooth muscle remodeling in asthma. Am J Respir Crit Care Med 2012: 185:715-722.

26. Lai $\mathrm{T}, \mathrm{Wu} \mathrm{D}$, Chen $\mathrm{M}$ et al. YKL-40 expression in chronic obstructive pulmonary disease: relation to acute exacerbations and airway remodeling. Respir Res 2016: 17:31.

27. Goleva E, Hauk PJ, Boguniewicz J et al. Airway remodeling and lack of bronchodilator response in steroid-resistant asthma. J Allergy Clin Immunol 2007: 120:1065-1072.

28. Regamey N, Ochs M, Hilliard TN et al. Increased airway smooth muscle mass in children with asthma, cystic fibrosis, and non-cystic fibrosis bronchiectasis. Am J Respir Crit Care Med 2008: 177:837-843.

This article is protected by copyright. All rights reserved. 
29. Song JS, You JS, Jeong SI et al. Serum periostin levels correlate with airway hyperresponsiveness to methacholine and mannitol in children with asthma. Allergy 2015: 70:674681.

30. Oostveen E, MacLeod D, Lorino H et al. The forced oscillation technique in clinical practice: methodology, recommendations and future developments. Eur Respir J 2003: 22:1026-1041.

This article is protected by copyright. All rights reserved. 
vii. Tables

Table 1. Baseline characteristics and lung function of the study children.

Study children $(n=49)$

Age (years)

Male sex

Allergic sensitization

$7.0(6.2 ; 7.7)$

$32(65 \%)$

$30(61 \%)$

Blood eosinophils $\left(10^{9} / \mathrm{l}\right)$

$0.43(0.20 ; 0.70)$

Blood neutrophils $\left(10^{9} / \mathrm{l}\right)$

$2.85(2.29 ; 3.53)$

Serum YKL-40 (ng/ml)

$23.0(18.0 ; 34.5)$

Serum periostin $(\mathrm{ng} / \mathrm{ml})$

$52.9(46.2 ; 62.0)$

Serum hs-CRP (mg/l)

$0.32(0.19 ; 0.98)$

$\mathrm{R5}(\mathrm{kPa} / \mathrm{l} / \mathrm{s})$

$0.79(0.70 ; 0.91)$

$0.16(-0.32 ; 1.12)$

R5 z-score (SD)

$0.59(0.53 ; 0.64)$

$-0.33(-1.08 ; 0.38)$

$0.20(0.12 ; 0.30)$

$1.29(0.32 ; 2.39)$

R5-20 z-score (SD)

$-0.24(-0.31 ;-0.20)$

X5 (kPa/l/s)

X5 z-score (SD)

$-0.63(-1.41 ; 0.07)$

$1.88(1.33 ; 2.68)$

$2.86(2.16 ; 3.67)$

$1.48(1.24 ; 1.70)$

$\operatorname{FEV}_{1}$ (l)

FEV $_{1}$ z-score (SD)

$-0.93(-1.45 ;-0.10)$

This article is protected by copyright. All rights reserved. 
FVC (l)

FVC z-score (SD)

$\mathrm{FEV}_{\mathbf{1}} / \mathrm{FVC}$

FEV $_{1} /$ FVC $_{\text {z-score (SD) }}$

FEF $_{50}(\mathbf{l} / \mathbf{s})$

FEF $_{50}$ z-score (SD)

$\mathrm{FeNO}_{50}(\mathrm{ppb})$

$\mathrm{FeNO}_{50} \mathrm{z}$-score (SD)

$\mathrm{C}_{\mathrm{ALV}}(\mathbf{p p b})$
$1.71(1.39 ; 2.05)$

$-0.35(-1.06 ; 0.40)$

$0.85(0.81 ; 0.91)$

$-0.85(-1.65 ; 0.03)$

$1.71(1.46 ; 2.00)$

$-0.92(-1.63 ;-0.30)$

$11.90(6.95 ; 20.70)$

$1.20(0.25 ; 2.80)$

$1.90(1.40 ; 3.06)$

Data presented as no. $(\%)$ or median (interquartile range). Abbreviations: AX, area under the reactance curve; $\mathrm{C}_{\mathrm{ALV}}$, alveolar nitric oxide concentration; $\mathrm{FEF}_{50}$, forced expiratory flow at $50 \%$ of the forced vital capacity; $\mathrm{FeNO}_{50}$, fractional exhaled nitric oxide at $50 \mathrm{ml} / \mathrm{s} ; \mathrm{FEV}_{1}$, forced expiratory volume in one second; FVC, forced vital capacity; hs-CRP, high-sensitivity C-reactive protein; R5 and R20, respiratory resistance at 5 and $20 \mathrm{~Hz}$, respectively; R5-20, difference between respiratory resistance at 5 and $20 \mathrm{~Hz}$; SD, standard deviation; X5, respiratory reactance at $5 \mathrm{~Hz}$.

This article is protected by copyright. All rights reserved. 
Table 2. Correlations between serum YKL-40, periostin, and high-sensitivity C-reactive protein (hsCRP) and baseline impulse oscillometry indices.

\begin{tabular}{|c|c|c|c|c|c|c|c|c|c|c|c|}
\hline & \multicolumn{2}{|c|}{ R5 } & \multicolumn{2}{|c|}{ R20 } & \multicolumn{2}{|c|}{ R5-20 } & \multicolumn{2}{|c|}{ X5 } & \multicolumn{2}{|c|}{$\mathbf{A X}$} \\
\hline & & $\mathrm{kPa} / \mathrm{l} / \mathbf{s}$ & $\begin{array}{c}\text { z- } \\
\text { score }\end{array}$ & $\mathrm{kPa} / \mathrm{l} / \mathrm{s}$ & $\begin{array}{c}\text { z- } \\
\text { score }\end{array}$ & $\mathrm{kPa} / \mathrm{l} / \mathbf{s}$ & $\begin{array}{c}\text { z- } \\
\text { score }\end{array}$ & $\mathrm{kPa} / \mathrm{l} / \mathbf{s}$ & $\begin{array}{c}\text { z- } \\
\text { score }\end{array}$ & $\mathrm{kPa} / \mathrm{l}$ & $\begin{array}{c}\text { z- } \\
\text { score }\end{array}$ \\
\hline Serum & $\mathbf{r}$ & 0.299 & 0.304 & 0.094 & 0.088 & 0.296 & 0.329 & $\mathbf{- 0 . 3 7 7}$ & -0.354 & 0.300 & 0.335 \\
\hline $\begin{array}{l}\text { YKL-40 } \\
(\mathrm{ng} / \mathrm{ml})\end{array}$ & $\mathbf{p}$ & 0.037 & 0.034 & 0.523 & 0.547 & 0.039 & 0.029 & 0.008 & 0.013 & 0.036 & 0.019 \\
\hline Serum & $\mathbf{r}$ & -0.024 & -0.011 & -0.189 & -0.054 & 0.052 & 0.068 & -0.157 & -0.201 & 0.113 & 0.117 \\
\hline$(\mathrm{ng} / \mathrm{ml})$ & $\mathbf{p}$ & 0.869 & 0.941 & 0.193 & 0.712 & 0.721 & 0.641 & 0.281 & 0.166 & 0.361 & 0.424 \\
\hline Serum & $\mathbf{r}$ & 0.068 & 0.148 & 0.098 & 0.217 & 0.029 & 0.067 & 0.014 & -0.048 & -0.010 & 0.112 \\
\hline $\begin{array}{l}\text { hs-CRP } \\
(\mathrm{mg} / \mathrm{l})\end{array}$ & $\mathbf{p}$ & 0.642 & 0.311 & 0.504 & 0.135 & 0.842 & 0.646 & 0.925 & 0.744 & 0.947 & 0.442 \\
\hline
\end{tabular}

Abbreviations: AX, area under the reactance curve; R5 and R20, respiratory resistance at 5 and $20 \mathrm{~Hz}$, respectively; R5-20, difference between respiratory resistance at 5 and $20 \mathrm{~Hz}$; X5, respiratory reactance at $5 \mathrm{~Hz}$.

This article is protected by copyright. All rights reserved. 


\section{viii. Figure legends}

Figure 1. Schematic illustration of impulse oscillometry indices respiratory resistance at 5 and $20 \mathrm{~Hz}$ (R5 and R20, respectively), respiratory reactance at $5 \mathrm{~Hz}$ (X5), and area under the reactance curve (AX).

Figure 2. Flowchart of the study. Abbreviations: FeNO, fractional exhaled nitric oxide; IOS, impulse oscillometry.

Figure 3. Association between significant airway hyperreactivity (AHR) or bronchodilator responsiveness (BDR) and serum level of (a) YKL-40 and (b) periostin. Results presented as individual data points and boxplots.

This article is protected by copyright. All rights reserved. 
Resistance (R)

$\mathrm{kPa} / \mathrm{l} / \mathrm{s}$

2.0

1.5

1.0

R5.

0.5
0.0

5

Frequency $(\mathrm{Hz})$
Reactance (X) $\mathrm{kPa} / \mathrm{l} / \mathrm{s}$

0.4

0.2

0.0

$-0.2$

$-0.4$
$25 \quad 30 \quad 35$

\section{)}




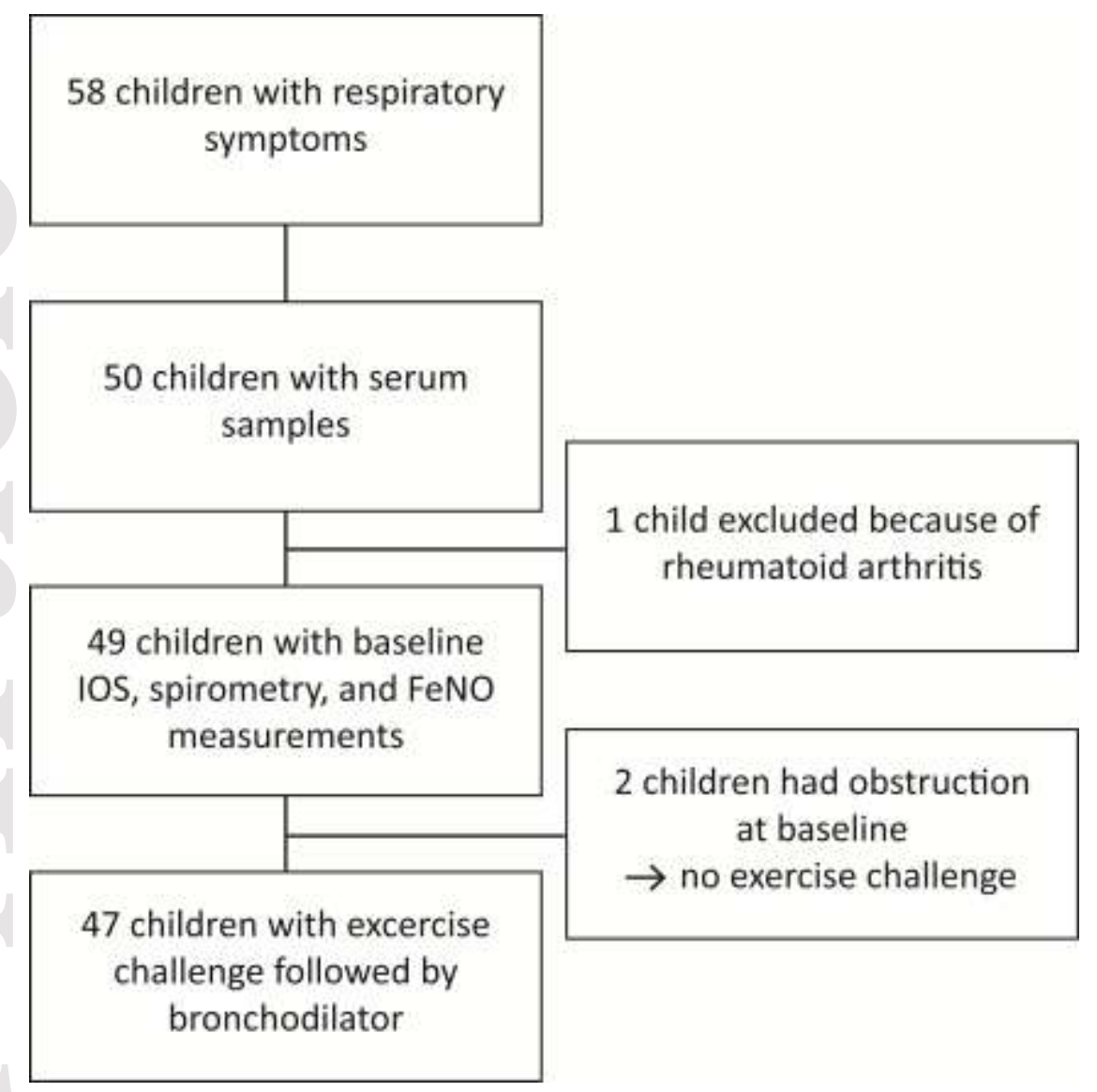

This article is protected by copyright. All rights reserved. 
(a)

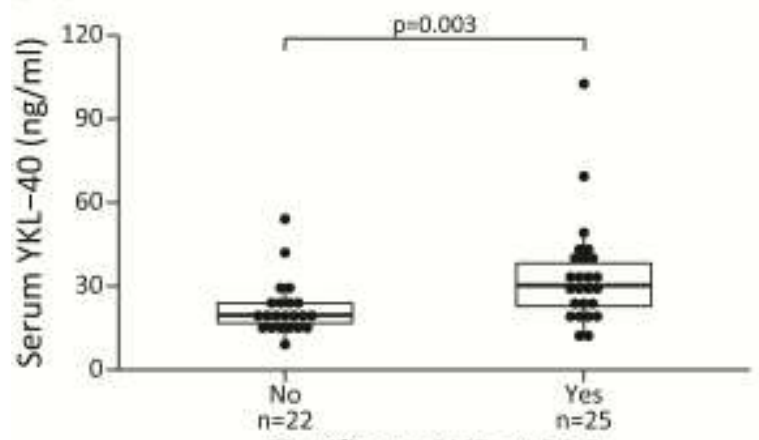

Significant AHR or BDR (b)

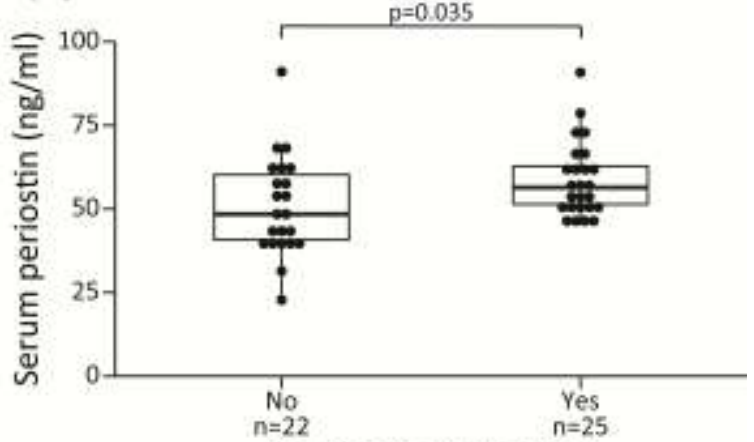

Significant AHR or BDR

This article is protected by copyright. All rights reserved. 